\title{
Audit results of the use of soft cast heel protection devices on patients with heel pressure ulceration
}

\author{
Keri Hutchinson", Ruth Alexander, Scott Cawley \\ From Society of Chiropodists and Podiatrists Annual Conference 2010 \\ Bournemouth, UK. 21-23 October 2010
}

\section{Introduction}

There is limited data available in the use of soft casting to offload heel ulceration. Heel pressure ulceration is a costly problem in the health board involved in this study with $15 \%$ of in-patients having heel pressure ulceration (HPU).This has led to heel ulcers coming under the 1000 lives campaign in Wales. Soft cast is a quick, cost effective treatment modality for foot ulceration which is largely untested on heel ulceration.

\section{Methods}

12 patients with HPU of grade II and above were issued with a soft cast heel protection device and monitored closely. Size and depth of the wound was recorded as was neurological and vascular status and VAS pain scale scores.

\section{Results}

12 patients were audited, 1 patient died in an unrelated adverse event and of the remaining 11 patients, $2 \mathrm{HPU}$ resolved and the remaining 9 patients ulcers all reduced in size and the wound beds improved. All 11 patients had significantly reduced pain scores with patient stories indicating good compliance and acceptability of the device.

\section{Discussion}

The audit results highlight a need for a research project in this area as the indications were that soft cast heel protection was a successful, cost effective modality for this patient group with the potential for reducing hospital stays and staff time costs.

Cardiff and Vale University Health board, Cardiff, Wales, UK
Published: 20 December 2010

doi:10.1186/1757-1146-3-S1-P12

Cite this article as: Hutchinson et al: Audit results of the use of soft cast heel protection devices on patients with heel pressure ulceration. Journal of Foot and Ankle Research 2010 3(Suppl 1):P12.
Submit your next manuscript to BioMed Central and take full advantage of:

- Convenient online submission

- Thorough peer review

- No space constraints or color figure charges

- Immediate publication on acceptance

- Inclusion in PubMed, CAS, Scopus and Google Scholar

- Research which is freely available for redistribution

\section{() Biomed Central}

\section{Biomed Central}

